\title{
Research on the Reform Method of Ideological and Political Courses in Colleges and Universities under the Background of Quality Education
}

\author{
Zhou Wang \\ Xi'an University, Xi'an Shaanxi, 710065
}

Keywords: Quality Education; Colleges and Universities; Ideological and Political Courses; Method

\begin{abstract}
The ideological and political courses is an important part of higher education. At present, Chinese higher education has developed to a new stage, and university curriculum reform has also entered the new area. How to do a good job in the reform of ideological and political courses in colleges and universities under the background of quality education is not only an educational issue, but also a social issue. The solution of this problem requires the joint efforts and advancement of the whole society. This paper analyzes the problems and drawbacks in the current ideological and political courses teaching in colleges and universities in China, and analyzes the methods and steps of ideological and political courses reform in colleges and universities under the background of quality education.
\end{abstract}

\section{Introduction}

College students are at a specific stage of their lives. At this stage, their education has a tremendous impact on their formation of world outlook, outlook on life and values. Ideological and political education is an indispensable part of a person's healthy growth. All countries in the world attach great importance to the ideological and political education of young students. Due to institutional reasons, the forms of education may not be the same.

In recent years, with the development of society and the progress of the times, especially with the continuous advancement of globalization, all kinds of thoughts continue to wash people's thinking. As a frontier that accepts all kinds of new trends of thought, the impact of students' thoughts can be imagined. The development of the Internet and modern technology has given students more access to information. The emergence of some bad ideas and values has distort the value orientation of some students, and some students have even experienced political confusion. In recent years, the vicious incidents in China's colleges and universities have a direct connection with the students' political stance and the decadence of ideas.

College ideological and political courses are one of the system components for building students' ideological defense. In the new historical period, especially in the context of advocating quality education, college ideological and political courses should adapt to this change. How to make the curriculum construction and reform orientation oriented to the needs of personnel training is an urgent and realistic issue before us. 


\section{Problems in the Current Ideological and Political Courses Education in Colleges and Universities}

If we want to promote the development of one thing, we must analyze the current problems of this matter. The author is engaged in the teaching of ideological and political courses in colleges and universities for many years. The author believes that the problems in the ideological and political curriculum education in colleges and universities in China can be summarized as follows.

\subsection{The Concept of Education Is Backward}

The concept of education is the foundation of education and teaching, and it has a decisive guiding role in education and teaching. At present, China is in a new stage of development, both economically and politically. At this stage, the demand for talent has changed dramatically from the past. In order to adapt to this change, many scholars have carried out many explorations and attempts in theory and practice. However, some college teachers are still relatively slow to reflect this change. They do not have a clear understanding of the role they should play in the new historical period. Some people are aware of it, but they do not pay enough attention to it. Many people are still using traditional teaching methods in education and teaching. Some teachers believe that the current society is centered on economic construction, and students only need to learn to earn money more than anything else. They believe that standardizing education on students' minds is not conducive to cultivating students' innovative thinking and is a kind of imprisonment for students. Some people think that ideological politics is a kind of imaginary thing and does not have much promotion effect on social development. There are many people who hold this view. Should we pay attention to the ideological and political education of students? I think the answer is unquestionable. We have had a painful lesson in this regard.

On the question of how to carry out the education of ideological and political courses, different people have different views on this. One of the more typical mistakes is to equate ideological and political education with traditional education. Ideological and political education is a traditional education, but it does not mean that our education methods must be old-fashioned. Today, with the development of informatization, some teachers still can't get rid of the traditional teaching methods when carrying out ideological and political courses. How much is the relationship between such backward education and teaching concepts and methods with traditional teaching methods? Here we put the backwardness of the educational concept in the first place, that is, it must play a sufficient vigilant role for everyone.

\subsection{Lack of In-depth and Meticulous Analysis of Students' Thinking}

One of the prerequisites and necessary conditions for us to do a good job in the education and teaching of ideological and political courses in colleges and universities is that we must fully understand students' thinking and situation. But at this point, our work is obviously lacking. Due to institutional reasons, college ideological and political courses is only a classroom course, and teachers generally only need to do classroom teaching. This has caused the disconnection between teachers and students to a certain extent. The teacher's task is to focus on the coursework, and to carry out the necessary ideological and political education for students on the basis of completing the coursework. The effect of this education is equal to the teaching outcome. The contact between teachers and students is basically limited to the classroom. In some ways, the follow-up of student thinking is done by a instructor. There are more communication with instructors in some specific things in student life and learning, which causes that teachers can't grasp the students' ideological status in a timely manner. The work that teachers can do is just to follow the instructions of the 
teaching progress.

With the improvement of material living standards, the current thinking of college students is relatively active. Some of them can't treat personal gains and losses correctly, some are confused about the future, some lack of ideals and convictions, and so on. Students in the higher education stage often have a strong self-esteem. Although they have certain resistance to the confusion and frustration they encounter, it is difficult to make a correct judgment on the origin of the matter because of the lack of social experience. However, they are not willing to communicate with others. This has resulted in the disconnection between teachers and students. The contradiction between teaching and learning is very prominent. The reason is that the way we work is not appropriate. We have not understand students' ideological situation deeply, and only are satisfied with the task of completing education and teaching.

\subsection{Pay Attention to Theory and Ignore Practice}

Many people think that political education is a theoretical indoctrination. In a narrow sense, this view is correct as political work is an ideological work. But in a broad sense, this view has great limitations. In order to achieve the desired results, political education must be closely integrated with practice. After all, education is different from research. Some schools do not pay attention to the artistry of political education. No matter what classroom teaching or daily education, they let students accept the content of ideological education in the passive regardless of occasions and objects. Young students are at a critical stage of mental growth, and they have a certain rebellious mentality about external pressures. Therefore, the cramming teaching method not only fails to achieve the expected results, but is often counterproductive. The education and teaching of ideological and political courses in colleges and universities has strict logic and science, and the practice links should occupy a considerable proportion in the ideological and political courses of colleges and universities. Regrettably, this issue has not received the attention it deserves for a long time.

Some schools have also carried out certain practical activities, such as students going to the countryside, community volunteers, etc. In fact, these activities are very good carriers of ideological and political education. However, if students are not properly guided in these activities, the purpose of ideological and political education is difficult to achieve. At present, the practice activities organized by schools have no actual effect. The focus of schools and teachers is often on whether the event is organized smoothly and whether it has achieved the set social impact, ignoring the correct guidance and education for students during the event.

\section{The Reform Methods and Strategies of Ideological and Political Courses in Colleges and Universities under the Background of Quality Education}

Quality education puts higher standards on teaching and learning. How to do a good job in the reform of ideological and political courses in colleges and universities under the background of quality education is an urgent problem that we face in the new historical period. Under the background of quality education, the reform of ideological and political education courses in colleges and universities is a systematic project. It cannot be done overnight and should not be delayed. We must follow the scientific and pragmatic attitude, step by step, scientific planning, and solid development.

\subsection{Pay Attention to Ideology}

From a certain perspective, ideological and political education is an important branch of 
humanities education, and it is also an important support for the entire social education system. For the guiding role of the teaching value of ideological and political education in colleges and universities in the new era, we should have a clear and profound understanding. We must abandon the interference of the misconceptions of the past and do a good job in the overall reform of the ideological and political education in colleges and universities in the new era. The focus of the work is to strengthen the comprehensive ideological and political accomplishment of college teachers and students, and take various measures to actively shape and cultivate students' good moral consciousness and ideas. From the perspective of the school, we must work hard to create a great atmosphere for the sound development of ideological and political education. In the construction of education and teaching system, we should extensively collect the needs of teachers and students to escort the discipline construction starting from the actual situation of the school. The majority of teachers should take the overall requirements of the times and the overall situation of discipline construction as their own responsibility, and fully tap the great role of ideological and political education in the reform of higher education teaching. The majority of students should have a full consideration of the social value of ideological and political education and teaching, and should not examine this subject from a one-sided perspective.

\subsection{Change the Traditional Education Teaching Mode}

The teaching of ideological and political education in colleges and universities is a bit boring compared to other disciplines. At the same time, because the teaching of ideological and political education is more abstract, the teaching is more difficult. The teaching of traditional ideological and political education has fundamentally not deviated from the traditional teaching method. Today, a variety of high-tech auxiliary education teaching methods have been widely used in the classroom and outside teaching. However, looking at the ideological and political education in China's colleges and universities, it seems that the research on the application of high-tech technology in education and teaching is still lagging behind. Young students are more interested in new things, and novel education and teaching methods tend to stimulate their enthusiasm and initiative. Judging from the application effect of new technology education and teaching methods, it is indeed more advantageous than the traditional way. We must work hard to change the traditional teaching mode of ideological and political education in colleges and universities, combine tradition with modernity, and completely change the current education and teaching dilemma.

We must work hard to do a good job in the practice of ideological and political courses education in colleges and universities. In practice planning, we must let students fully appreciate the charm of ideological and political education in the hands-on practice based on the principle of easy operation and controllable risks. In practice, we must be good at guiding students to refine the truth and sublimate the soul from what they see and have learned. After the practice, we can organize students to discuss, so that everyone can speak fully, and raise personal understanding into a consensus of activities.

\subsection{Improve the Curriculum System}

At present, the ideological and political curriculum system of colleges and universities is still not perfect. The development of education and teaching is mainly based on the classroom, and it has not fully penetrated into the daily work and study of students. This is the focus of the reform and construction of the ideological and political curriculum system in colleges and universities under the background of quality education. At present, the hardware construction of campus network in China has been basically completed, and the information-based education and teaching mode can play a huge role in the education of ideological and political courses in colleges and universities. 
The current trend of global education reform is to focus on the individuality of the individual being educated, to carry out personalized education that suits individual characteristics, and to emphasize the individualized development of students. This has something in common with the quality education advocated by China at present. At present, multimedia are widely used. These are just the most basic applications of education and teaching under the conditions of information and internet. Education and teaching under the conditions of informatization and internet can separate lecture from listening. The student's study and the teacher's teaching is no longer limited by the time and place, and the form of education and teaching has been greatly expanded. At the same time, informatization makes the content of learning rich and colorful, which will definitely enhance students' interest in learning and stimulate their desire to learn.

\section{Conclusion}

With the development of the economy and the progress of society, the state's requirements for the cultivation of talents are constantly improving. How to do a good job in the ideological and political education of colleges and universities in the new historical period is not only related to the long-term development of the discipline, but also to the success or failure of the teaching reform in colleges and universities. We must do this work with a high sense of mission and responsibility, and contribute to the healthy development of college English teaching.

\section{References}

[1] Chen Yonggang. Discussion on the Problems of Ideological and Political Education and the Countermeasures in Colleges and Universities in China [J]. Science \& Technology Economic Market, 2016 (6).

[2] Liu Jingwei and Li Jungang. Problems in the Teaching of Ideological and Political Theory Courses for Graduate Students and the Countermeasures in Colleges and Universities-Taking the Universities in Heilongjiang Province as an Example [J]. Heilongjiang Higher Education Research, 2015 (1).

[3] Cai Yangbo. Thoughts on the Teaching Problems of Ideological and Political Courses and Countermeasures in Local Colleges and Universities [J]. Journal of Xiangfan Vocational and Technical College, 2012, (11).

[4] Luo Yun. A Summary of Studies on Several Issues of Ideological and Political Education in Colleges and Universities [J]. Educational Observation, 2012 (10).

[5] Pei Jianwei. Research on the Practice of College Students' Ideological and Political Education in the New Situation

[J]. China Electric Power Education, 2011 (11).

[6] Wang Dexun. Research on the Innovation of Ideological and Political Work in Colleges and Universities [J]. Heilongjiang Higher Education Research, 2007 (12). 